\title{
Control of Fusarium wilt in wheat seedlings by grain priming with defensin-like protein
}

Deyala M. Naguib

\begin{abstract}
The exogenous application of natural plant resistance inducer is a new interesting way for disease management. From this point of view, this study investigated the effect of wheat grain priming with defensin on the resistance of the grown plants against the Fusarium wilt. The results showed that priming enhanced the antioxidant system represented in antioxidant enzymes (superoxide dismutase, polyphenol oxidase, soluble and cell wall-bound peroxidase) and non-enzymatic antioxidant compounds (proline, free soluble and cell wall-bound phenols) in the plants. This results in decreasing the $\mathrm{H}_{2} \mathrm{O}_{2}$ content and lipid peroxidation in these plants, which protects plants from the oxidative stress. Defensin priming not only improved the antioxidant system but also improved the hydrolysis processes. Under infection, the protease activity in the primed plants decreased compared to its highly significant increase in the non-primed group. Defensin priming also increased the activity of the phosphatases and amylase which increased the soluble phosphate and sugar. This served the high metabolic activity of the defensin-primed plants. The highly significant decrease in the shikimic acid content in the defensin-primed group ensured its high metabolic activity. All these changes are initiated by the regulation of defense signal molecules such as jasmonic and abscisic acids. This helped the plants grown from defensin-primed grains to overcome the Fusarium infection.
\end{abstract}

Keywords: Antioxidant compounds, Jasmonic acid, Abscisic acid, Shikimic acid, Proteases, Phosphatases

\section{Background}

The exogenous application of natural plant resistance inducer is a new interesting way for diseases management. It is more effective and safe for the environment and so human health. The use of natural products can enhance the response against the attack of a wide range of pathogens (Oliveira et al. 2016).

Octadecanoid pathway is one of the important defense mechanisms against pathogens. Through this pathway, jasmonic acid is formed activating the expression of several defense genes. Also, $\mathrm{H}_{2} \mathrm{O}_{2}$ is formed during this pathway. $\mathrm{H}_{2} \mathrm{O}_{2}$ is considered to be the first defense-signaling molecule in plants. A number of other reactive oxygen species (ROS) constantly produced under stress. The increase in ROS production is highly dangerous on cellular macromolecules such as lipids, proteins, and nucleic acids. Several antioxidant enzymes and compounds are enabled to fight the dangerous effect of the ROS. However, this defensive system is often insufficient to fight severe stress

Correspondence: Dmna2610science@yahoo.com

Botany Department, Faculty of Science, Zagazig University, Zagazig, Egypt conditions. From this point of view, finding exogenous additives to counter ROS-induced injury symptoms and enhance stress tolerance in plants and their parts is highly important need (Chandrakar et al. 2018).

Defense-related enzymes play an important protective role in plants against pathogen invasion. Many studies have reported that superoxide dismutase (SOD), peroxidase (POX), and polyphenol oxidase (PPO) are from the most important defense-related enzymes in plants. SOD, POX, and PPO are representative antioxidant enzymes and are important components of defense against membrane lipid peroxidation and oxidative stress during pathogen invasion. Beside these antioxidant enzymes there are another nonenzymatic antioxidant compounds such as phenols and proline. The soluble phenols play an important role in redox regulation in plant tissues and can act as antimicrobial compounds. Also, the esterification of phenols in the cell wall (lignification) is an effective defense mechanism against pathogen invasion spread (Han et al. 2016). Proline is very important amino acid in plants. It has many functions under stress such as osmolyte, an antioxidative 
molecule and a signaling molecule (Hayat et al. 2012). Shikimic acid is the known precursor of aromatic amino acids and many secondary metabolites important in resistance mechanism such as phenols specially the lignin (Nadernejad et al. 2013).

The abscisic acid (ABA) is well known as stress hormones. It regulates many metabolic processes involved in plants under stress conditions. ABA initiates defense mechanisms, such as controlling the closing and opening of stomata and expression of defense-related genes (Agarwal and Jha 2010).

Plant defensins are small, cysteine-rich proteins (45-54 amino acids). They have been separated from many plant species and tissues. They have a lot of different functions. Mainly, they have antifungal activity; also, they have a role as an antibacterial agent, zinc tolerance, and blocking of ion channels, as well as inhibition of proteases (Oddepally and Guruprasad 2015).

Fusarium oxysporum is a soilborne fungal pathogen. It causes major economic losses by inducing necrosis and wilting symptoms in various crop plants. Mainly, farmers fight the Fusarium by the use of chemical fungicides. These are injurious to the environment, and their efficiency is often limited by pathogenic variability. Hence, improving safe and effective new strategies for fighting the soilborne pathogens is an urgent need (Swarupa et al. 2014). From this point of view, this present study aimed to introduce a natural, safe, and effective strategy to fight the Fusarium wilt. The effect of wheat grains priming with defensin (natural defense peptide) on the biochemical response of wheat seedlings to fight the $\mathrm{Fu}$ sarium wilt was evaluated.

\section{Materials and methods}

\section{Extraction and purification of defensin from Trigonella foenum-graecum seeds}

The natural defensin from 50-g powdered Fenugreek (Trigonella foenum-graecum) seeds, FD, was extracted and purified, according to Oddepally and Guruprasad (2015) as follows: Fine flour (100 g) was prepared from the seeds of Fenugreek in a mill. A protein extract was prepared from this flour, using $500 \mathrm{ml}$ of extraction buffer $\left(10 \mathrm{mM} \mathrm{Na} 2 \mathrm{HPO}_{4}, 15 \mathrm{mM}\right.$ $\mathrm{NaH}_{2} \mathrm{PO}_{4}, 100 \mathrm{mM} \mathrm{KCl}, 1.5 \%$ EDTA, pH 5.4) for $2 \mathrm{~h}$ at $4{ }^{\circ} \mathrm{C}$ with constant agitation. This protein extract was centrifuged at $15,000 \mathrm{~g}$, and the supernatant was fractionated at $70 \%$ relative ammonium sulfate saturation at $4{ }^{\circ} \mathrm{C}$ for $18 \mathrm{~h}$. After centrifugation under the same conditions, the precipitate was re-dissolved in distilled water and heated at $80^{\circ} \mathrm{C}$ for $15 \mathrm{~min}$ in a water bath. This heated protein extract was centrifuged at $3000 \mathrm{rpm}$ for $5 \mathrm{~min}$. The supernatant was recovered and extensively dialyzed against distilled water for 3 days and then recovered by freeze-drying. For peptides, purification was initially performed on a DEAE-Sepharose column (with $100 \mathrm{ml}$ of resin), equilibrated with $20 \mathrm{mM}$ Tris- $\mathrm{HCl}$
(pH 8.0), at a flow rate of $60 \mathrm{ml} / \mathrm{h}$. The freeze-dried protein extract $(50 \mathrm{mg}$ ) was reconstituted in $5 \mathrm{ml}$ of the equilibrium buffer and centrifuged $\left(6000 \mathrm{rpm}, 3 \mathrm{~min}\right.$ at $\left.4{ }^{\circ} \mathrm{C}\right)$, and the supernatant was loaded onto the column. A non-retained fraction (D1) was eluted in the equilibrium buffer and used as defensin source. The protein content in the purified extract and the crude extract was determined by Lowry et al. (1951) method and subjected to protein electrophoresis.

\section{Culturing of plant pathogenic fungus}

Fusarium oxysporum was friendly obtained from Assistant Professor: Manal Tawfik, Assistant Professor of Mycology, Botany Department, Faculty of Science, Zagazig University, Egypt.

The fungus spores were prepared by growing the organism on Hordeium grains medium. Five hundred-milliliter flasks, containing 100-g washed Hordeium grains and 80 - $\mathrm{mL}$ tap water, were autoclaved at $121 \pm 1{ }^{\circ} \mathrm{C}$ for $15 \mathrm{~min}$. The autoclaved Hordeium grains were inoculated with the fungus under aseptic conditions and incubated at $25 \pm 1{ }^{\circ} \mathrm{C}$ for 21 days. The medium was mixed and rubbed together to release mycelium and spores from Hordeium grains. The mycelium and spores were taken in sterile water and used for inoculation of plants. Calculate spores concentration using a hemocytometer. Prepare $10^{6}$ spores $/ \mathrm{ml}$ suspensions in autoclaved distilled water for inoculation (Hegazy 2008).

\section{Pot experiment}

Wheat (Triticum aestvium L.; cultivar Sakha 96) grains were obtained from the Agricultural Research Center, Giza, Egypt.

Pot experiments were carried out in the greenhouse of the Botany Department, Faculty of Science, Zagazig University, Egypt. Plastic pots (20-cm diameters) were filled with about $2 \mathrm{~kg}$ of soil (peat moss soil) each. The pots were divided into two groups. The first remained as it is, while the second was infected by $100 \mathrm{ml}$ of the prepared $F$. oxysporum spore suspension.

Grains were surface sterilized by $0.1 \%$ mercuric chloride solution followed by rinsing with distilled water. A group of the seeds was soaked in the purified extracted defensin solution for $12 \mathrm{~h}$ then dried again to get rid of excess moisture (defensin-primed group), and the other group was kept dry (non-primed group). Each group was planted in the plastic pots (seven grains in each pot). Pots were arranged on the greenhouse benches and kept under natural photoperiod (12 to $13 \mathrm{~h})$, temperature $\left(28 \pm 4^{\circ} \mathrm{C}\right)$ and irrigated weekly. Samples were collected after 10 days (1st stage) and 20 days (2nd stage). The experiment was done in triplicate.

\section{Markers of oxidative stress}

$\mathrm{H}_{2} \mathrm{O}_{2}$ content in 1-g fresh leaves was determined according to the method of Alexieva et al. (2001).

MDA (malonyldialdehyde) determination in 1-g fresh leaves has followed the method described by Li (2000). 


\section{Antioxidant activity}

Five-gram fresh leaves were homogenized in $0.05 \mathrm{M}$ cold phosphate buffer ( $\mathrm{pH}$ 6.5) containing $1 \mathrm{mM}$ EDTA, $\mathrm{Na}_{2}$ and centrifuged at $3800 \mathrm{~g}$ for $10 \mathrm{~min}$. The supernatant was completed to a total known volume $(5 \mathrm{ml})$ and used as the protein and enzyme source. The residue was carefully washed with distilled water and centrifuged several times. The wall fraction was then kept with $10 \mathrm{ml}$ of $1 \mathrm{M} \mathrm{NaCl}$ for $1 \mathrm{~h}$ to release cell wall-bound POX and centrifuged at $3800 \mathrm{~g}$ for $10 \mathrm{~min}$; the supernatant was used as the source of wall-bound POX (Saroop et al. 2002).

SOD activity was measured by the nitro blue tetrazolium (NBT) reduction method (Beyer and Fridovich 1987). PPO was estimated according to Kar and Mishra (1976). Soluble and cell wall-bound (POX) was determined according to Saroop et al. (2002). The enzymes' activity was expressed as $\mathrm{U} \mathrm{mg}^{-1}$ protein $\mathrm{min}^{-1}$.

Free and cell wall-bound phenols were extracted from 1-g leaves of both control and treated plants according to the method of Campbell and Ellis (1992).

Proline content was determined in $1 \mathrm{~g}$ of Fresh leaves according to the method of Bates et al. (1973).

\section{Determination of hydrolysis processes Carbohydrates hydrolysis}

The amylase activity was measured according to Johnson (2007) and expressed as the amount of starch hydrolyzed min $^{-1}$ mg protein ${ }^{-1}$.

Carbohydrates were estimated in $1 \mathrm{~g}$ of fresh leaves according to phenol-sulfuric acid method (Dubois et al. 1956).

\section{Organic phosphorus hydrolysis}

The activities of the two enzymes were assayed depending on the method of Tominaga and Takeshi (1974). One nkat of enzyme activity was defined as $1 \mathrm{nmol}$ p-nitrophenol liberated $\mathrm{min}^{-1}$ and specific activity as nkat $\mathrm{mg}^{-1}$ protein.

For determination of the total phosphorus content, $5 \mathrm{~g}$ of dried powder of plants was digested in a mixture of concentrated nitric acid, sulfuric acid, and perchloric acid at the ratios 10:1:4, respectively. The volume was made up to a constant volume with distilled water according to the method of Chapman and Pratt (1978). Phosphorus content in the digested samples was determined according to Murphy and Riley (1958). Results were expressed as milligrams per gram dry weight.

\section{Protein hydrolysis}

Protease activity was measured in an azocasein assay (Mel et al. 2000). Specific enzyme activity was expressed as change in optical density $\mathrm{mg}^{-1}$ protein $\mathrm{min}^{-1}$.

The total protein content was identified according to the method of Lowry et al. (1951).
Total free amino acids were estimated in $1 \mathrm{~g}$ of fresh leaves according to the method of Lee and Takahashi (1965).

\section{Metabolic activity marker (shikimic acid) content}

Shikimic acid concentration in $1 \mathrm{~g}$ of fresh leaves was determined according to Zelya et al. (2011). The frozen plant

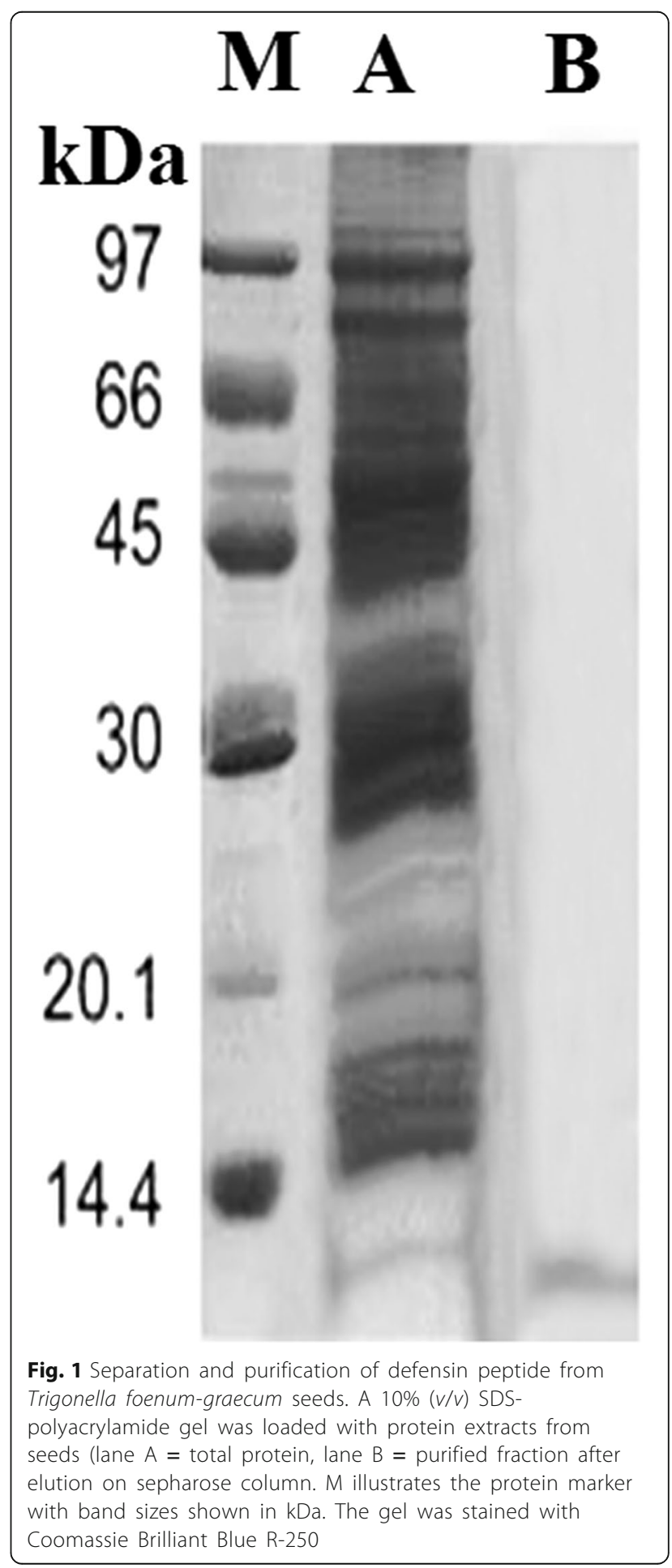


leaves or calli were ground $(0.2 \mathrm{~g})$ before $1 \mathrm{ml} / 100 \mathrm{mg}$ biomass of $0.25 \mathrm{M} \mathrm{HCl}$ was added. The extracts were shaken ( $2 \mathrm{~min}$.) and then centrifuged at $3800 \mathrm{~g}$ for $30 \mathrm{~min}$. The supernatant $(50 \mu \mathrm{l})$ reacted with $0.5 \mathrm{~mL}$ of a $1 \%$ solution of periodic acid. After $3 \mathrm{~h}$ at room temperature, $0.5 \mathrm{ml}$ of $1 \mathrm{M}$ sodium hydroxide and $0.3 \mathrm{ml}$ of $0.1 \mathrm{M}$ glycine were added per sample. Samples were centrifuged again and absorbance measured at $380 \mathrm{~nm}$. The amount of shikimic acid in the test sample was calculated using the standard curve.

\section{Hormones}

The method of hormone extraction was essentially similar to that adopted by Shindy and Smith (1975) and described by Hashem (2006). To estimate the amounts of acidic hormones abscisic acid (ABA), the plant hormone fractions and standard ones were methylated according to Vogel (1975) to be ready for gas chromatography (GC) analysis. Flame ionization detector was used for the identification and determination of acidic hormones using Hewlett Packard Gas Chromatography (5890) fitted and equipped with HP-130 $\mathrm{mx} 0.32 \mathrm{~mm} \times 0.25 \mathrm{~mm}$ capillary column coated with methyl silicone. The column oven temperature was programmed at $10{ }^{\circ} \mathrm{C} \mathrm{min}{ }^{-1}$ from $200{ }^{\circ} \mathrm{C}$ (5 min) to $260{ }^{\circ} \mathrm{C}$ and kept finally to $10 \mathrm{~min}$. Injector and detector temperature were 260 and $300{ }^{\circ} \mathrm{C}$, respectively. Gas flow rates were 30,30 , and $300 \mathrm{~cm} \mathrm{~s}^{-1}$ for $\mathrm{N}_{2}, \mathrm{H}_{2}$, and air, respectively, and flow rate inside column was adjusted to $2 \mathrm{ml} \mathrm{min}{ }^{-1}$. Jasmonic acid (JA) was determined, according to Kramell et al. (1997) using NUCLEODEX beta-PM, $200 \mathrm{~mm}$ and $4 \mathrm{~mm}$ ID column, flow rate adjusted at $1 \mathrm{ml} \mathrm{min}{ }^{-1}$ and detected at UV $210 \mathrm{~nm}$. Standards of ABA and JA were used.

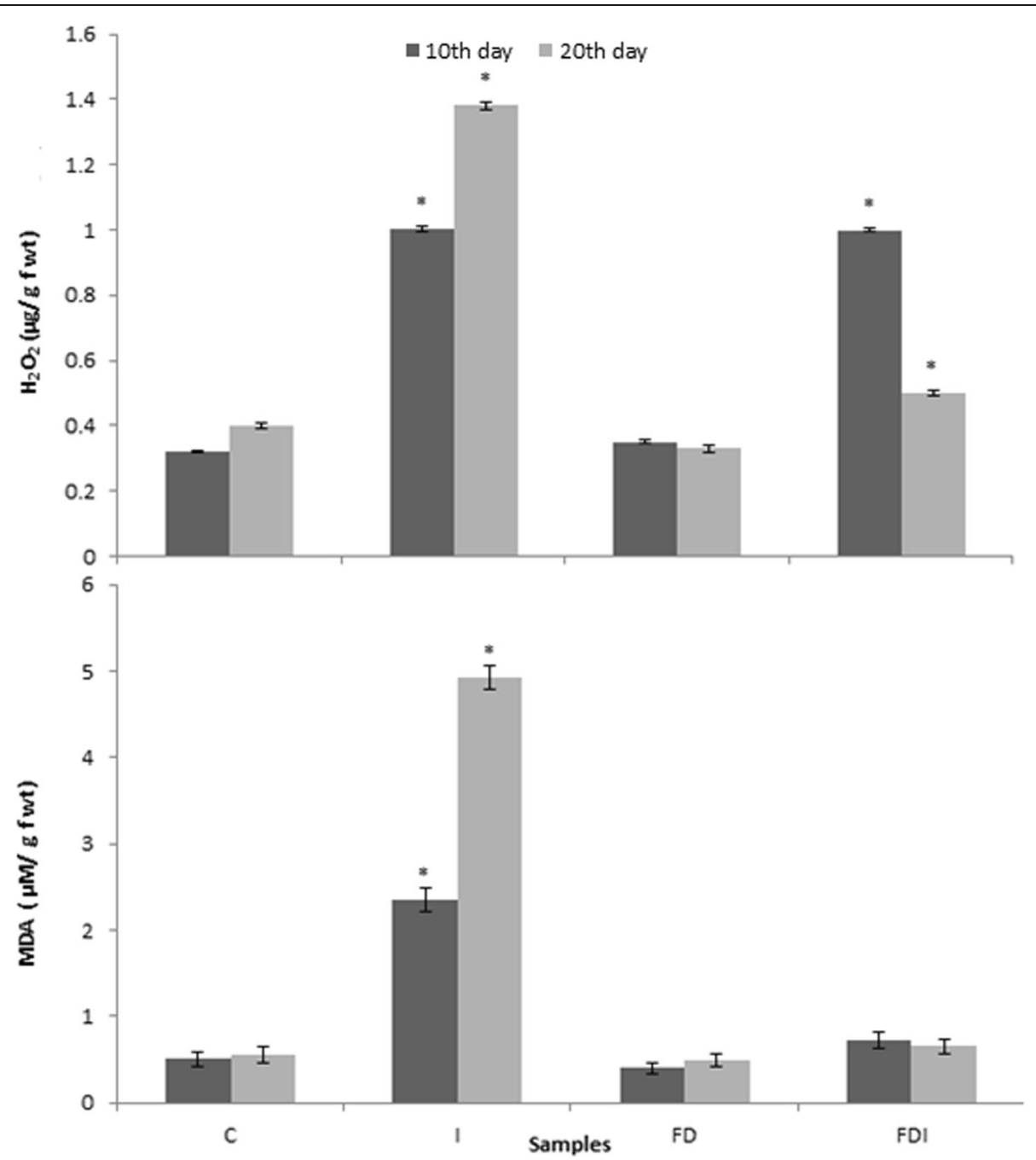

Fig. 2 Effect of defensin priming on oxidative stress markers $\left(M D A\right.$ and $\mathrm{H}_{2} \mathrm{O}_{2}$ ) in plants under Fusarium infection. C: control plants (plants grown from non-primed grains in non-infected soil, FD: plants grown from defensin-primed grains in non-infected soil, I: plants grown from non-primed grains in Fusarium-infected soil and FDI: plants grown from defensin-primed grains in Fusarium-infected soil. The columns followed by asterisks are significantly different from the control according to paired-sample $t$ test. The bars represent the standard error. Values are means of three replicates 
Peak identification was performed by comparing the relative retention time of each peak with those of $A B A$ and JA standards. Peak area was measured by triangulation, and the relative properties of the individual components were therefore obtained at various retention times.

\section{Statistical analysis}

All results were analyzed by SPSS software (version 14). Data was expressed as mean \pm SD. Comparison of mean values of the sample and the control was done, using paired $T$ test. $P$ $<0.05$ was considered to be significant (Levesque 2007).

\section{Results and discussion}

\section{Extraction and purification of defensin}

The SDS page ensured that the purified protein used in the research was a single band with $10 \mathrm{kDa}$ molecular weight (Fig. 1). The protein content in the crude extract was $158.928 \mathrm{mg}^{2}$ protein $\mathrm{g}^{-1}$ dry weight. The protein content in the purified defensin was about $0.492 \mathrm{mg}_{\text {protein }} \mathrm{g}^{-1}$ dry weight. This result is correlated to Oddepally and Guruprasad (2015).

\section{Effect of defensin priming on antioxidant machinery in wheat seedlings during Fusarium wilt control}

Seed priming is an interesting alternative way in disease management. The results of the present study ensured that priming of the wheat grains with defensin improved the biochemical response of the wheat seedlings against the infection of $F$. oxysporum. The activities of the antioxidant enzymes (SOD, PPO, soluble and cell wall-bound POX) in the FDI and I group were significantly higher than that in the $\mathrm{C}$ group at 10th day. At the 20th day, the enzymes' activity remained in the FDI group significantly higher than that in the control, while in the I group their activities significantly decreased compared to that at the 10th day (Fig. 3). This activation of the antioxidant system could reflect a defense response to the cellular damage caused by pathogen toxins (Chandrakar et al. 2018). This role was clearly showed in the results of the MDA
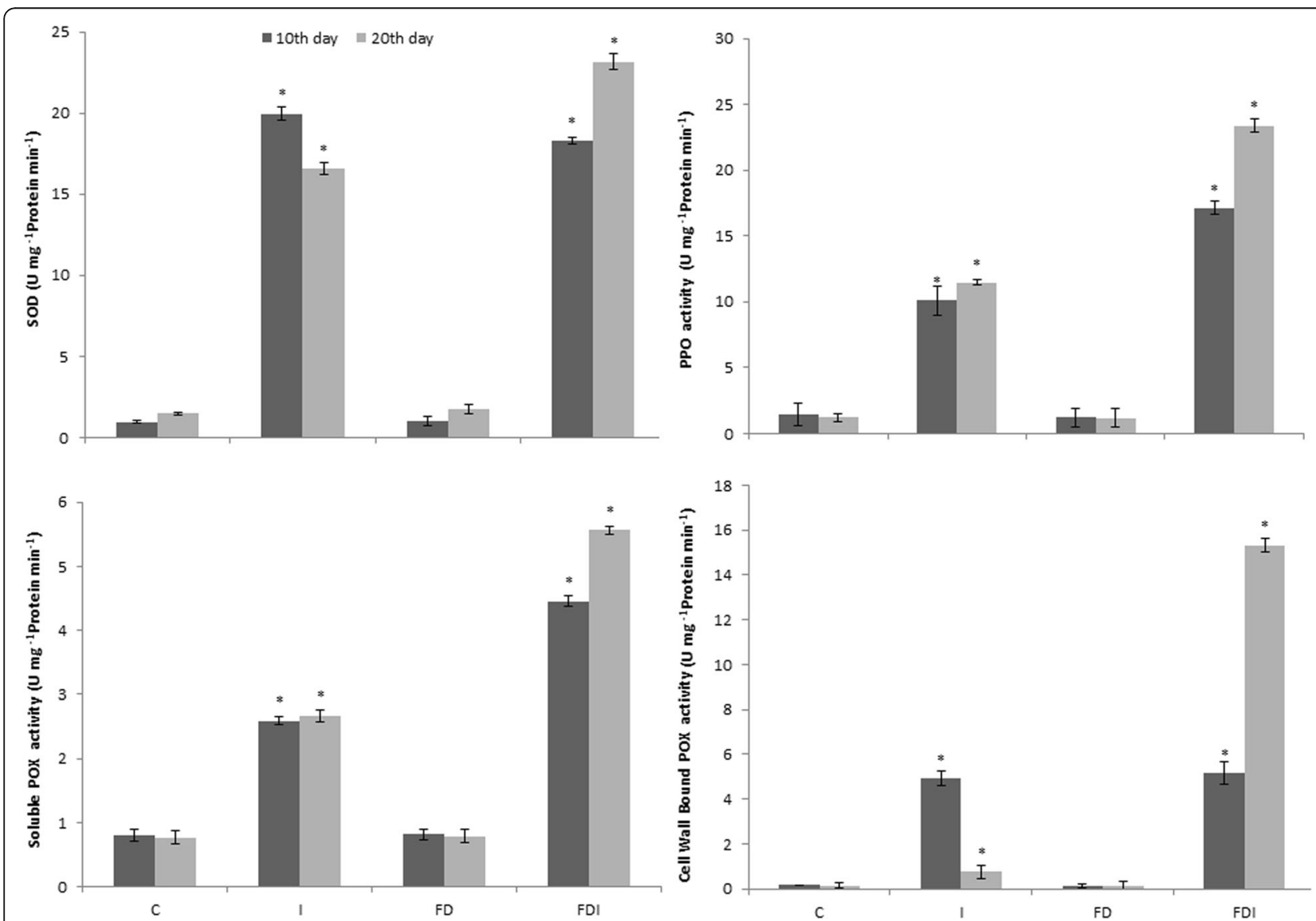

Fig. 3 Effect of defensin priming on antioxidant enzymes (SOD, PPO, soluble and cell wall bound POX) in plants under Fusarium infection. C Control plants (plants grown from non-primed grains in non-infected soil, FD: plants grown from defensin primed grains in non-infected soil, I: plants grown from non-primed grains in Fusarium infected soil and FDI: plants grown from defensin primed grains in Fusarium infected soil. The columns followed by asterisks are significantly different from the control according to paired-samples $t$ test. The bars represent the standard error. Values are means of three replicates 
content, one of lipid peroxidation (LPO) products. Obtained results showed that MDA significantly increased continuously in the I group but in the FDI groups insignificantly increased at 10th day then decreased at 20th day (Fig. 2). This increase in LPO may be related to increase in the ROS against the antioxidant system, which loses its activity with increasing the stress time. It has been found that plants exposed to various stress exhibit an increase in LPO due to the generation of ROS (Han et al. 2016). As indicated and clarified in $\mathrm{H}_{2} \mathrm{O}_{2}$ content in the results, $\mathrm{H}_{2} \mathrm{O}_{2}$ content increased significantly under infection either in the case of defensin-primed plants (FDI) or non-primed plants (I) at the 10th day (210.9 and $212.14 \%$, respectively). $\mathrm{H}_{2} \mathrm{O}_{2}$ content in the FDI group significantly decreased at the 20th day. The content decreased significantly to be only about $17.5 \%$ more than that of the control (C). In the I group, the content of $\mathrm{H}_{2} \mathrm{O}_{2}$ increased significantly to be $245.25 \%$ more than that of the $\mathrm{C}$ (Figs. 2 and 3). The increase of $\mathrm{H}_{2} \mathrm{O}_{2}$ content, as a result of stress, can be explained by activation of NADPH-dependent oxidases and cell wall-bound peroxidase as stress response, such as reported by Agarwal and Jha (2010) who reported that during stress, there is an activation in the transcription of NADPH-dependent oxidases genes. In FDI group, the $\mathrm{H}_{2} \mathrm{O}_{2}$ content significantly increased at 10th day and then decreased at 20th day. This increase is attributed to the fact that $\mathrm{H}_{2} \mathrm{O}_{2}$ can act as a signal molecule involved in acclamatory signaling triggering tolerance against various stress (Miller et al. 2010).

$\mathrm{H}_{2} \mathrm{O}_{2}$ content decreased again with time in the FDI group but increased in the other treatment; as in the FDI group antioxidant network (enzymatic and non-enzymatic), it was active, which is constantly acting on the alert for rising $\mathrm{H}_{2} \mathrm{O}_{2}$ concentrations and provides effective scavenging for it. $\mathrm{H}_{2} \mathrm{O}_{2}$ is involved in cell wall reinforcement by increasing protein cross-linking and incorporation of phenolics in the cell wall (lignification), which is an effective defense mechanism to both biotrophics and necrotrophics (Han et al. 2016). This is correlated to the results in Fig. 4,
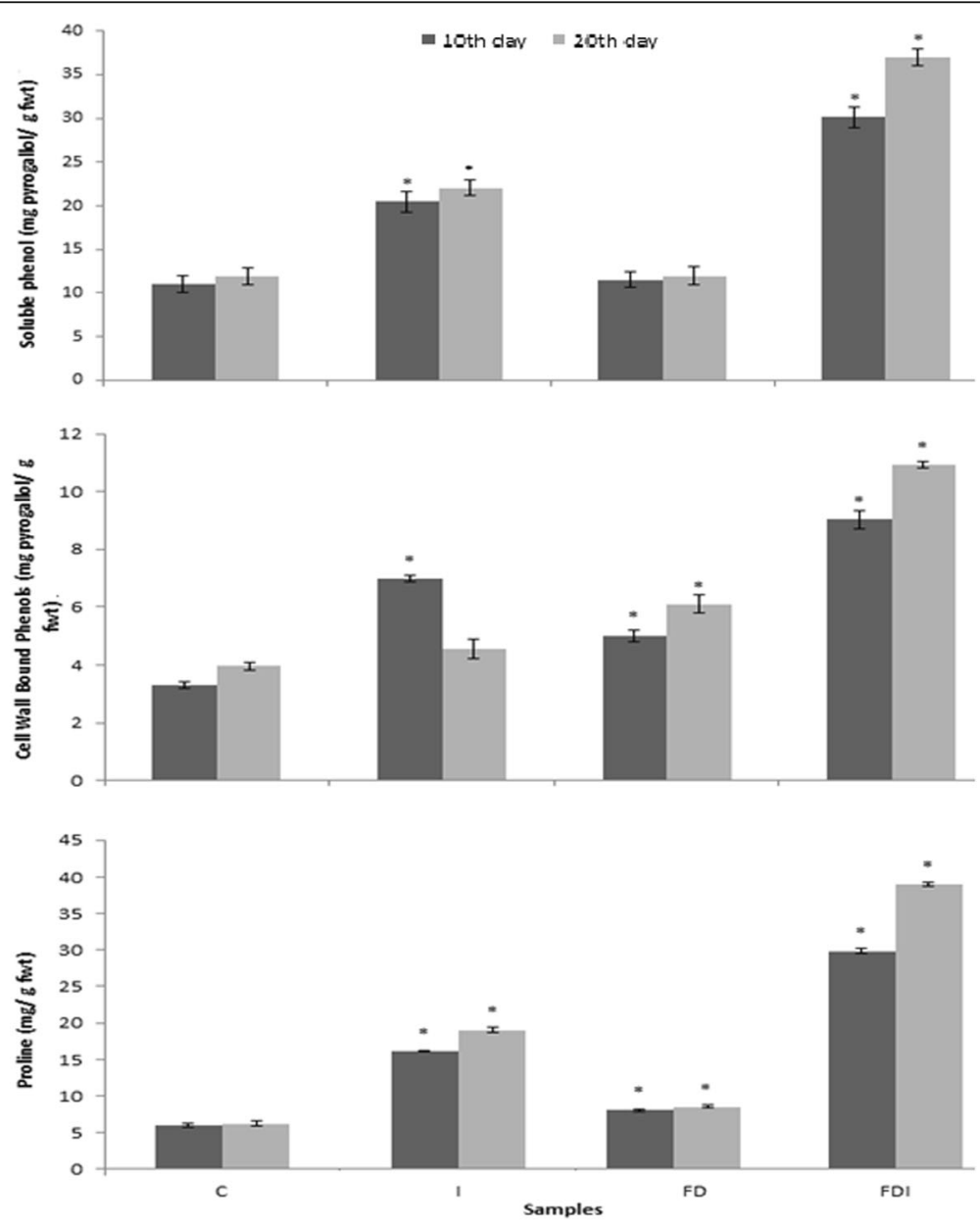

Fig. 4 Effect of defensin priming on antioxidant compounds (free soluble and cell wall bound phenols and proline) in plants under Fusarium infection. C: Control plants (plants grown from non-primed grains in non-infected soil, FD: plants grown from defensin primed grains in non-infected soil, l: plants grown from non-primed grains in Fusarium infected soil and FDI: plants grown from defensin primed grains in Fusarium infected soil. The columns followed by asterisks are significantly different from the control according to paired-samples $t$ test. The bars represent the standard error. Values are means of three replicates 
Table 1 Effect of defensin priming on protein hydrolysis (soluble protein, protease activity and free amino acids) in plants under Fusarium infection conditions

\begin{tabular}{|c|c|c|c|c|c|c|}
\hline \multirow[t]{2}{*}{ Sample } & \multicolumn{2}{|c|}{ Soluble protein ( $\left.\mathrm{mg} \mathrm{g}^{-1} \mathrm{fwt}\right)$} & \multicolumn{2}{|c|}{ Protease activity (change in optical density $\mathrm{mg}^{-1}$ protein $\mathrm{min}^{-1}$ ) } & \multicolumn{2}{|c|}{ Free amino acids ( $\left.\mathrm{mg} \mathrm{g}^{-1} \mathrm{fwt}\right)$} \\
\hline & 1st Stage & 2nd Stage & 1st Stage & 2nd Stage & 1st Stage & 2nd Stage \\
\hline $\bar{C}$ & $31.09 \pm 0.078$ & $32.67 \pm 0.092$ & $0.0093 \pm 0.097$ & $0.0095 \pm 0.271$ & $2.5 \pm 0.148$ & $2.89 \pm 0.109$ \\
\hline । & $19.28 \pm 0.165^{*}$ & $13.09 \pm 0.109^{*}$ & $0.024 \pm 0.196^{*}$ & $0.032 \pm 0.192^{*}$ & $11.98 \pm 0.265^{*}$ & $18.2 \pm 0.213^{*}$ \\
\hline FD & $36.9 \pm 0.056^{*}$ & $38.94 \pm 0.208^{*}$ & $0.00756 \pm 0.083^{*}$ & $0.00708 \pm 0.098^{*}$ & $1.56 \pm 0.095$ & $1.230 \pm 0.109^{*}$ \\
\hline $\mathrm{FDI}$ & $30.98 \pm 0.023$ & $31.27 \pm 0.107$ & $0.0097 \pm 0.309$ & $0.0098 \pm 0.192$ & $3.09 \pm 0.104$ & $3.15 \pm 0.056$ \\
\hline
\end{tabular}

Values are given as means of 3 replicates \pm standard error

C, Control plants grown from non-primed grains in uninfected soil; FD, plants grown from defensin primed grains in uninfected soil; I, plants grown from nonprimed grains in Fusarium infected soil and FDI, plants grown from defensin primed grains in Fusarium infected soil

Within a column, means followed by asterisks are significantly different from the control according to paired-samples $t$ test

which showed the changes in the content of the non-enzymatic antioxidant compounds (free soluble or cell wall-bound phenol) or proline. In FDI and I groups free soluble phenol and proline contents were significantly higher than that in the $\mathrm{C}$ group at both days. In the case of cell wall-bound phenols, content in the FDI was significantly higher than that in the control either at 10th or 20th day, while in the I group, its content was significantly higher than that in the control at 10th day and then decreased at 20th day to be lower than that in the control. This ensured the dual role of $\mathrm{H}_{2} \mathrm{O}_{2}$ stress reported by Miller et al. (2010).

\section{Effect of defensin priming on metabolic status in wheat seedlings during Fusarium wilt disease}

The increase in the reactive oxygen species $\left(\mathrm{H}_{2} \mathrm{O}_{2}\right)$ under stress leads to increase in the proteolysis (Miller et al. 2010). This is clarified in obtained results as protein content in the FD group was $19.19 \%$ higher than that in control. Correlated to protein content in the FD group, the protease activity and free amino acid content were 25.47 and $57.44 \%$, respectively, lower than that in the control. In the FDI group, the protein content became insignificantly lower than that in the control. In the I group, the protein content was 59.9\% lower than that in the control. In the I group, the protease activity and free amino acid content were 236.84 and $529.75 \%$, respectively, higher than that in the control (Table 1).
This agrees with the fact that defensins have a role in the inhibition of proteases enzymes (van der Weerden and Anderson 2013).

Defensin not only modulated the antioxidant machinery and the protein hydrolysis process but also defensin priming enhanced the carbohydrates hydrolysis in FD plants. Soluble carbohydrate content was $12.3 \%$ higher than that in the control. Amylase activity was $46.7 \%$ higher than that in the control. In the I group, the soluble carbohydrate content and the amylase activity significantly decreased. In the FDI, the soluble carbohydrates and amylase activity remained significantly higher than the content and activity in the control (Table 2).

Similar to carbohydrate hydrolysis, the acid and alkaline phosphatase activity and soluble phosphate content in the FD group were significantly higher than the activity and content in the control. In the I group, the acid and alkaline phosphatase activity and soluble phosphate contents were $57.6,56.3$, and $78.65 \%$, respectively, lower than the activity and content in the control. In the FDI group, phosphatases activity and the soluble phosphate content became insignificantly higher than the activity and content in the control (Tables 3 and 1). This increased the soluble phosphate and soluble sugars which considered the main energy requirements in the cell (Nasri et al. 2015).

The increase in soluble sugar and soluble phosphate in FDI content serves the carbon fluxes from primary to secondary metabolic pathways. The stimulation of

Table 2 Effect of defensin priming on carbohydrates hydrolysis (soluble carbohydrates and amylase activity) in plants under Fusarium infection

\begin{tabular}{|c|c|c|c|c|}
\hline \multirow[t]{2}{*}{ Sample } & \multicolumn{2}{|c|}{ Soluble carbohydrates (mg glucose/g fwt) } & \multicolumn{2}{|c|}{ Amylase activity (mg starch hydrolyzed/min/mg protein) } \\
\hline & 1st Stage & 2nd Stage & 1st Stage & 2nd Stage \\
\hline $\mathrm{C}$ & $65.98 \pm 0.0483$ & $68.78 \pm 0.0893$ & $3.26 \pm 0.0945$ & $4.52 \pm 0.1467$ \\
\hline । & $34.98 \pm 0.1982^{*}$ & $26.03 \pm 0.0724^{*}$ & $2.05 \pm 0.0659^{*}$ & $2.12 \pm 0.1342^{*}$ \\
\hline $\mathrm{FD}$ & $76.42 \pm 0.0738^{*}$ & $77.23 \pm 0.0684^{*}$ & $4.92 \pm 0.1003^{*}$ & $6.63 \pm 0.0583^{*}$ \\
\hline FDI & $73.78 \pm 0.0389^{*}$ & $75.95 \pm 0.1982^{*}$ & $3.95 \pm 0.0678^{*}$ & $6.27 \pm 0.0451^{*}$ \\
\hline
\end{tabular}

Values are given as means of 3 replicates \pm standard error

C, Control plants grown from non-primed grains in uninfected soil; FD, plants grown from defensin primed grains in uninfected soil; I, plants grown from nonprimed grains in Fusarium infected soil and FDI, plants grown from defensin primed grains in Fusarium infected soil

Within a column, means followed by asterisks are significantly different from the control according to paired-samples $t$ test 
Table 3 Effect of defensin priming on organic phosphate hydrolysis (soluble phosphate and acid and alkaline phosphatases activity) in plants under Fusarium infection

\begin{tabular}{|c|c|c|c|c|c|c|}
\hline \multirow[t]{2}{*}{ Sample } & \multicolumn{2}{|c|}{ Soluble phosphate (mg/g dry wt) } & \multicolumn{2}{|c|}{ Alkaline phosphatase activity (nkat/mg protein) } & \multicolumn{2}{|c|}{ Acid phosphatase activity (nkat/mg protein) } \\
\hline & 1st Stage & 2nd Stage & 1st Stage & 2nd Stage & 1st Stage & 2nd Stage \\
\hline C & $13.72 \pm 0.068$ & $15.04 \pm 0.192$ & $37.04 \pm 0.098$ & $39 \pm 0.07795$ & $42.18 \pm 0.049$ & $44.89 \pm 0.098$ \\
\hline I & $4.68 \pm 0.1925^{*}$ & $3.21 \pm 0.0933^{*}$ & $19.37 \pm 0.088^{*}$ & $17.03 \pm 0.094^{*}$ & $22.09 \pm 0.157^{*}$ & $19.03 \pm 0.169^{*}$ \\
\hline FD & $17.14 \pm 0.344^{*}$ & $18.58 \pm 0.210^{*}$ & $42.46 \pm 0.196^{*}$ & $43.98 \pm 0.105^{*}$ & $47.98 \pm 0.119^{*}$ & $50.05 \pm 0.103^{*}$ \\
\hline FDI & $13.82 \pm 0.139$ & $15.52 \pm 0.311$ & $37.58 \pm 0.307$ & $38.78 \pm 0.079$ & $42.89 \pm 0.249$ & $45 \pm 0.0958$ \\
\hline
\end{tabular}

Values are given as means of 3 replicates \pm standard error

C, Control plants grown from non-primed grains in uninfected soil; FD, plants grown from defensin primed grains in uninfected soil; I, plants grown from nonprimed grains in Fusarium infected soil and FDI, plants grown from defensin primed grains in Fusarium infected soil

Within a column, means followed by asterisks are significantly different from the control according to paired-samples $t$ test

secondary metabolic pathways ensured by the results of shikimic acid content is shown in (Fig. 5). Shikimic acid content in the FDI was significantly lower than the content in the control plants. Under infection conditions, the shikimic acid content significantly decreased either in the FDI or I group. Its content in the FDI group was $81.6 \%$ lower than the content in the control. In the case of the I group, its content was $19.3 \%$ lower than that in the control. This accumulation of the shikimic acid related to the lower content of soluble carbohydrates and soluble phosphates. Thus, there were not enough sources for carbon fluxes for production of phenols through shikimic acid pathway. This explanation agrees with Cipollini et al. (2003) who reported that defense system impose metabolic costs on the plants by lowering the primary metabolites used in the fitness and growth of the plants. Therefore, only resistant plants can defend themselves through increasing the primary metabolites (soluble carbohydrates) to be sufficient for fit growth and formation of defensive secondary compounds.

\section{Effect of defensin priming on hormonal content in wheat seedlings during Fusarium wilt control}

Phytohormones are critical to the ability of plants to defend themselves against pathogens by modulating a wide range of adaptive responses ( $\mathrm{Di}$ et al. 2016). The present work showed that ABA content in the FDI group was higher than the content in the control only at 10th day and decreased to be lower than its content in the control at 20th day. On the other hand, in the I group, the ABA content was higher than its content in the control either at the 10th day or the 20th day (Fig. 6). The difference in the ABA content in the samples with the time is accumulating evidence suggests that for the development of plant resistance, short-term increase in the ABA level is critical during the early stages of plant interaction with stress. This regulates defense responses through its effects on callose deposition, production of reactive oxygen intermediates, and regulation of defense gene expression (Agarwal and Jha 2010). At the same time, high ABA concentrations maintained for a long time reduced the efficiency of defense systems controlled

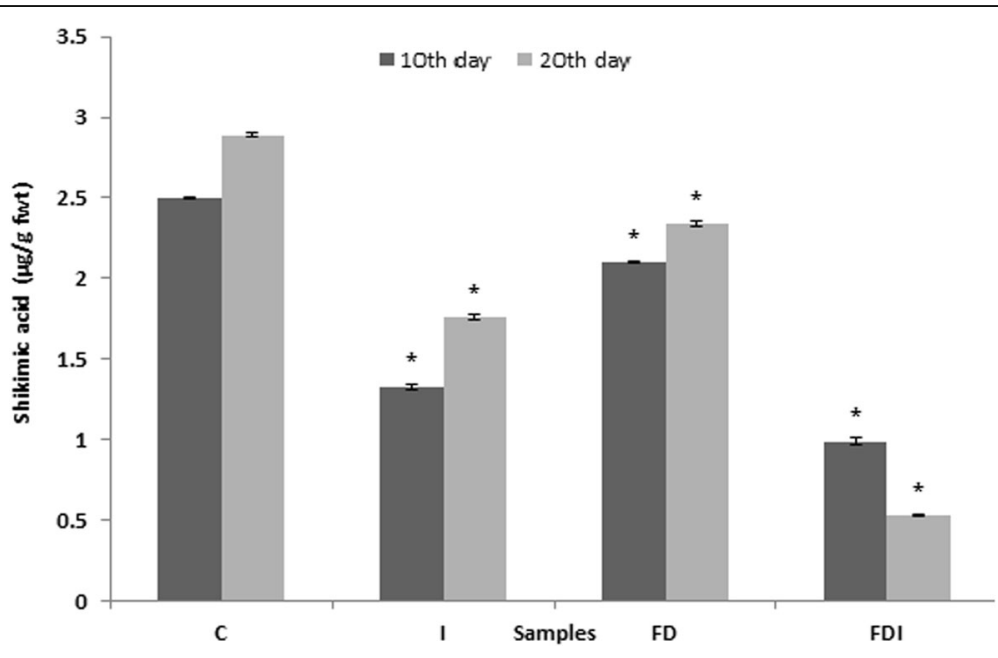

Fig. 5 Effect of defensin priming on Shikimic acid content in plants under Fusarium infection. C: Control plants (plants grown from non-primed grains in non-infected soil, FD: plants grown from defensin primed grains in non-infected soil, I: plants grown from non-primed grains in Fusarium infected soil and FDI: plants grown from defensin primed grains in Fusarium infected soil. The columns followed by asterisks are significantly different from the control according to paired-samples $t$ test. The bars represent the standard error. Values are means of three replicates 

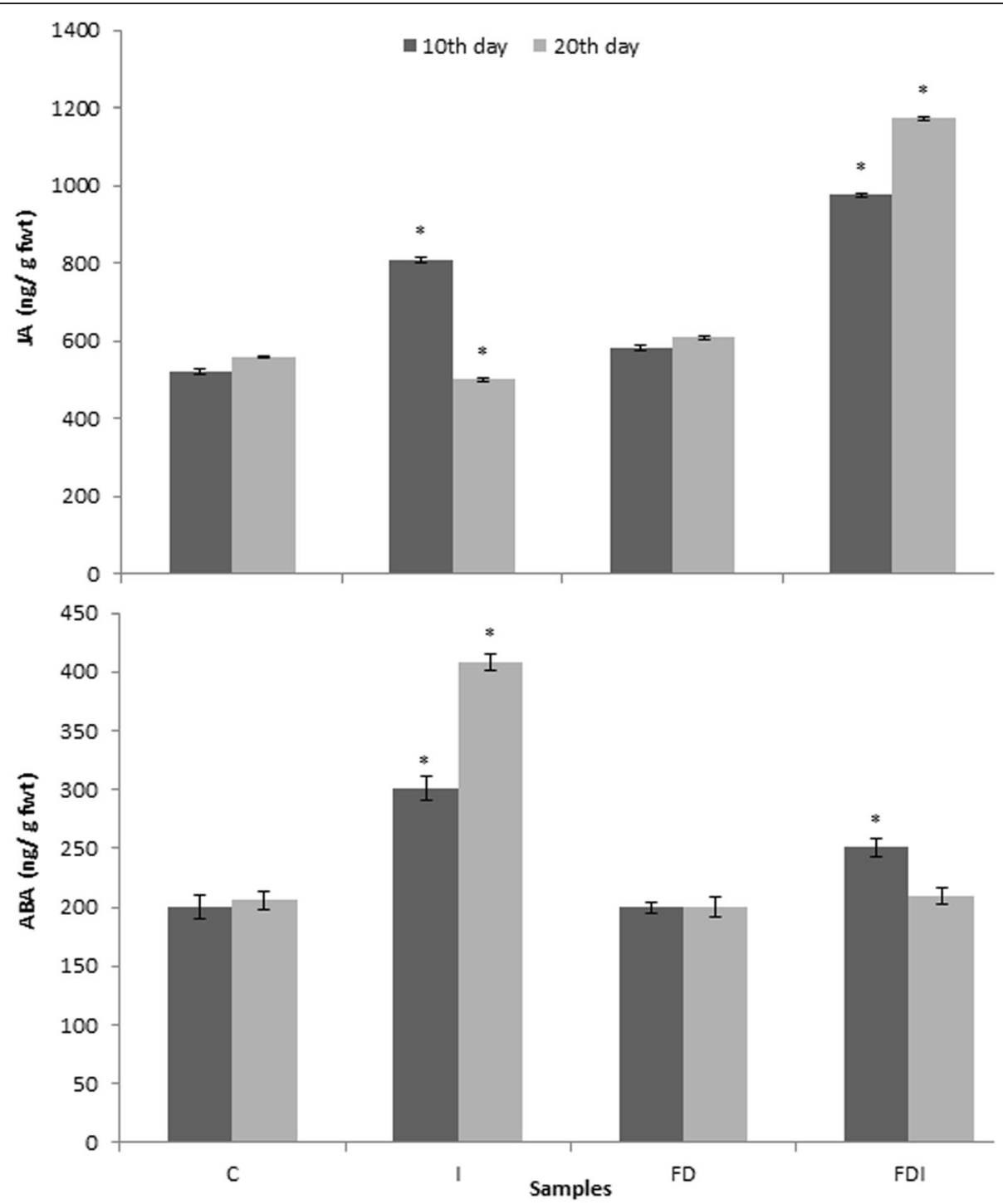

Fig. 6 Effect of defensin priming on Hormones content (JA and ABA) in plants under Fusarium infection. C: Control plants (plants grown from nonprimed grains in non-infected soil, FD: plants grown from defensin primed grains in non-infected soil, l: plants grown from non-primed grains in Fusarium infected soil and FDI: plants grown from defensin primed grains in Fusarium infected soil. The columns followed by asterisks are significantly different from the control according to paired-samples $t$ test. The bars represent the standard error. Values are means of three replicates

by salicylic, jasmonic acids, and ethylene. This assured that ABA is involved in plant defense mechanisms against pathogens as a regulatory element (Taki-Nakano et al. 2014).

The increase in JA content during stress is well documented as defense signal. Both $\mathrm{H}_{2} \mathrm{O}_{2}$ and JA are primary signaling molecules during the cellular response involved in saponin biosynthesis mediated by oligogalacturonic acid (OGA), which also leads to the $\mathrm{H}_{2} \mathrm{O}_{2}$-mediated upregulation of JA (Schaller and Stintzi 2009). Jasmonic acid induces glutathione, an important antioxidant for redox balance. Increased expression of nuclear factor erythroid 2-related factor 2 (NrF2) was also observed, which reduced the ROS level induced by $\mathrm{H}_{2} \mathrm{O}_{2}$ (Taki-Nakano et al. 2014). This explained the significant increase in JA content and decrease in the $\mathrm{H}_{2} \mathrm{O}_{2}$ content at the 20th day in the FDI plants. Decreasing of JA with time in the case of the I group can be attributed to the antagonistic effect of the accumulation of $\mathrm{ABA}$ in the tissues, while this antagonism not occurred in the FDI plants. Schaller and Stintzi (2009) reported that stress conditions alter oxylipin profiles, particularly the allene oxide synthase branch of the oxylipin pathway, responsible for production of jasmonic acid (JA) and its precursor 12-oxo-phytodienoic acid (12-OPDA). ABA signal pathway use the 12-OPDA which cause its unavailability for JA biosynthesis. In Arabidopsis, ABA has been shown to antagonize the JA signaling pathway, and this antagonism is considered responsible for the 
enhancement of disease susceptibility by ABA against the soilborne fungus $F$. oxysporum (Anderson et al. 2004).

\section{Conclusion}

The overall conclusion is that priming wheat grains with defensin resulted in growing plants able to defend themselves against $F$. oxysporum infection. This is ensured by comparing the biochemical changes in primed plants (FDI) and non-primed plant (I) infected with Fusarium. These changes were analyzed at two stages of disease establishment, the first at 10th day (the first record for symptoms at the I group appearance) and the second stage at 20th day (after which the I group plants died). The biochemical changes showed that defensin priming caused in regulating the signal molecules such as $\mathrm{ABA}$ and JA, and this, in turn, activates the antioxidant machinery. This antioxidant machinery succeeded in ameliorating the toxic effect of the reactive oxygen species represented in the decrease in $\mathrm{H}_{2} \mathrm{O}_{2}$ content and so decrease in the lipid peroxidation. This decreasing in the reactive oxygen species had a role in proteases inhibition, which increased the protein content and decreased the free amino acids content. Besides, the defensin priming improved the activities of the amylase and phosphatases which increased the content of soluble sugars and phosphate. These act as the main energy requirements in the cells; this serves the highly metabolically active status of the primed plants which ensured the low content of the shikimic acid.

\section{Acknowledgements}

I would like to express my great gratitude to my supervisor Professor Hegazy S. Hegazy, Professor of Physiology, for his effort, time, and patience given Also, I would like to thank Assistant Professor Manal Tawfik, Professor of Mycology, for her effort in the culturing of the plant pathogenic fungus (Fusarium oxysporum) used in this study.

\section{Funding}

This paper is self-funded, and I did not take any fund from any organization or person.

\section{Availability of data and materials}

All data generated or analyzed during this study are included in this published article.

\section{Author's contribution \\ I am responsible for the whole article. The author read and approved the final manuscript.}

\section{Ethics approval and consent to participate}

Not applicable

\section{Consent for publication}

Not applicable

\section{Competing interests}

The author declares no competing interests.

\section{Publisher's Note}

Springer Nature remains neutral with regard to jurisdictional claims in published maps and institutional affiliations.

Received: 7 June 2018 Accepted: 7 August 2018

Published online: 17 August 2018

\section{References}

Agarwal PK, Jha B (2010) Transcription factors in plants and ABA dependent and independent abiotic stress signaling. Biol Plant 54:201-212

Alexieva V, Sergio I, Mapelli S, Karanov E (2001) The effect of drought and ultraviolet radiation on growth and stress markers in pea and wheat. Plant Cell Enviro 24:1337-1344

Anderson JP, Badruzsaufari E, Schenk PM, Manners JM, Desmond OJ, Ehlert C, Maclean DJ, Ebert PR, Kazan K (2004) Antagonistic interaction between abscisic acid and jasmonate-ethylene signaling pathways modulates defense gene expression and disease resistance in Arabidopsis. Plant Cell 16:3460-3479

Bates LS, Waldren RP, Tear ID (1973) Rapid determination of free proline for water stress studies. Plant Soil 39:205-207

Beyer JR, Fridovich WF (1987). Assaying for superoxide dismutase activity: Some large consequences of minor changes in conditions. Anal Biochem 161: 559566.

Campbell MM, Ellis BE (1992) Fungal elicitor-mediated responses in pine cell cultures. Planta 186:409-417

Chandrakar V, Dubey A, Keshavkant S (2018) Modulation of arsenic-induced oxidative stress and protein metabolism by diphenyleneiodonium, 24epibrassinolide and proline in Glycine max L. Acta Bot Croat 77:51-61

Chapman HD, Pratt PF (1978) Methods of analysis for soils, in plant and water. Univ Calif, Dept Agric Sci, USA 50:309

Cipollini D, Purrington CB, Bergelson J (2003) Costs of induced responses in plants. Basic Appl Ecol 4:79-85

Di X, Takken FLW, Tintor N (2016) How phytohormones shape interactions between plants and the soil-borne fungus Fusarium oxysporum. Front Plant Sci 7:170

Dubois M, Gilles KA, Hamilton JK, Rebers PA, Smith F (1956) Colorimetric method for determination of sugars and related substances. Anal Chem 28:350-356

Han YQ, Li P, Gong SL, Yang L, Wen LZ, Hou ML (2016) Defense responses in rice induced by silicon amendment against infestation by the leaf folder Cnaphalocrocis medinalis. PLoS One 11:e0153918 https://doi.org/10.1371/ journal.pone.0153918

Hashem HA (2006) Physiological and molecular actions of jasmonic acid on soybean plant. Thesis, Faculty of Science, Ain Shams University, Cairo, Egypt, Ph. D, 145pp

Hayat S, Hayat Q, Alyemeni MN, Wani AS, Pichtel J, Ahmad A (2012) Role of proline under changing environments: a review. Plant Signal Behav 7: 1456-1466

Hegazy HS (2008) The role of heavy metals on metabolism of polyamines in bean plants (Vicia Faba) and its susceptibility to Fusarium wilt. Res J Agric Biol Sci 4:198-202

Johnson R (2007) Measuring amylase activity in cereal grains. Colby J Res Meth 9:11-13

Kar M, Mishra D (1976) Catalase, peroxidase and polyphenol oxidase activities during rice leaf senescence. Plant Physiol 57:315-319

Kramell R, Schneider G, Miersch O (1997) Chiral separation of amide conjugates of jasmonic acid by liquid chromatography. Chromatog 45:104-108

Lee YP, Takahashi T (1965) An improved colorimetric determination of amino acids with the use of ninhydrin. Anal Biochem 14:71-77

Levesque $R$ (2007). SPSS programming and data management: guide for SPSS and SAS users, fourth edition, SPSS Inc., Chicago, IL 60606-6412

Li HS (2000) Principles and techniques of plant physiological biochemical experiment, 2nd edn. Higher Education Press, Beijing, China, pp 260-263

Lowry O, Rosebrough NJ, Farr AL, Randall RJ (1951) Protein measurement with the Folin phenol reagent. J Biol Chem 193:265-275

Mel SF, Fullner KJ, Wimer-Mackin S, Lencer WI, Mekala-nos JJ (2000) Association of protease activity in Vibrio cholera vaccine strains with decrease in transcellular epithelial resistance of polarized T84 intestinal cells. Infect Immun 68:6487-6492

Miller G, Suzuki N, Ciftci-Yilmaz S, Mittler R (2010) Reactive oxygen species homeostasis and signalling during drought and salinity stress. Plant Cell Environ 33:453-467 
Murphy J, Riley JP (1958) Single-solution method for the determination of soluble phosphate in sea water. J Mar Biol Assoc UK 37:9-14

Nadernejad N, Ahmadimoghadam A, Hossyinifard J, Poorseyedi S (2013) Evaluation of PAL activity, phenolic and flavonoid contents in three pistachio (Pistacia vera L.) cultivars grafted on to three different rootstocks. J Stress Physiol Biochem 9:84-97

Nasri N, Saïdi I, Kaddour R, Lachaâl M (2015) Effect of salinity on germination, seedling growth and acid phosphatase activity in lettuce. Am J Plant Sci 6:57-63

Oddepally R, Guruprasad L (2015) Isolation, purification, and characterization of a stable Defensin_Like antifungal peptide from Trigonella foenum_graecum (fenugreek) seeds. Biochem Mosc 80:332-342

Oliveira MDM, Varanda CMR, Félix MRF (2016) Induced resistance during the interaction pathogen $\mathrm{x}$ plant and the use of resistance inducers. Phytochem Lett 15:152-158

Saroop S, Chanda SV, Singh YD (2002) Changes in soluble and ionically bound peroxidase activities during Brassica juncea seed development. Bulg J Plant Physiol 28:26-34

Schaller A, Stintzi A (2009) Enzymes in jasmonate biosynthesis structure, function, regulation. Phytochem 70:1532-1538

Shindy WW, Smith O (1975) Identification of plant hormones from cotton ovules. Plant Physiol 55:550-554

Swarupa V, Ravishankar KV, Rekha A (2014) Plant defense response against Fusarium oxysporum and strategies to develop tolerant genotypes in banana. Planta 239:735-751

Taki-Nakano N, Ohzeki H, Kotera J, Ohta H (2014) Cytoprotective effects of 12-oxo phytodienoic acid, a plant-derived oxylipin jasmonate, on oxidative stressinduced toxicity in human neuroblastoma SH-SY5Y cells. Biochem Biophys Acta 1840:3413-3422 https://doi.org/10.1016/j.bbagen.2014.09.003

Tominaga N, Takeshi M (1974) A sulfite dependent acid phosphatase of Thiobacillus thioxidans. J Biochem 76:419-428

van der Weerden NL, Anderson MA (2013) Plant defensins: common fold, multiple functions. Fungal Biol Rev 26:121-131

Vogel AJ (1975). A text book of practical organic chemistry, $3^{\text {rd }}$ ed., English Language Book Society and Longman Group Ltd: 843-845

Zelya IA, Anderson JAH, Owen MDK, Es RDL (2011) Evalution of spectrophotometric and HPLC methods for shikimic acid determination in plants: models in glyphosate resistant and susceptible crops. J Agri Food Chem 59:2202-2212

\section{Submit your manuscript to a SpringerOpen ${ }^{\circ}$ journal and benefit from:}

- Convenient online submission

- Rigorous peer review

- Open access: articles freely available online

- High visibility within the field

- Retaining the copyright to your article

Submit your next manuscript at $\boldsymbol{\nabla}$ springeropen.com 